\title{
Kepemimpinan Perempuan dalam Menciptakan Sekolah Ramah Anak
}

\author{
Hasan Baharun \\ Universitas Nurul Jadid, Probolinggo, Indonesia \\ ha54nbaharun@gmail.com \\ Adi Wibowo \\ STAI An-Nawawi, Purworejo, Indonesia \\ adiwibowohmp@gmail.com \\ Siti Nur Hasanah \\ Universitas Nurul Jadid, Probolinggo, Indonesia \\ hasanahofficial17@gmail.com
}

\begin{abstract}
The purpose of this study was to determine the leadership of women in creating child-friendly schools in RA Nurus Salam, Sambirampak Kidul, Kotaanyar, Probolinggo. The type of research used is quantitative research with a case study observation approach. The results showed, first, the leadership in RA Nurus Salam was a woman who wanted to create a child-friendly school. Second, the implementation of childfriendly schools has been implemented in RA Nurus Salam with the following stages; first, Word Analysis. Second, the Branding School. Third, Implementation of Sra Development. Fourth, Continuous Improvement. With the implementation of child-friendly schools in RA Nurus, the learning greetings are more conducive and the trust of parents to teachers is getting higher.
\end{abstract}

Keywords: Women's Leadership; Child Friendly Schools; Early Childhood 


\begin{abstract}
Abstrak
Penelitian ini bertujuan untuk menganalisis dan memahami tentang kepemimpinan perempuan dalam menciptakan sekolah ramah anak di Raulatul Athfal (RA) Nurus Salam, Sambirampak Kidul, Kotaanyar, Probolinggo, Jawa Timur. Penelitian ini menggunakan pendekatan kualitatif jenis fenomenologi. Hasil penelitian menunjukkan bahwa, pertama kepemimpinan di RA Nurus Salam adalah seorang perempuan yang ingin menciptakan sekolah ramah anak. Kedua, penerapan sekolah ramah anak sudah dilaksanakan di RA Nurus Salam dengan tahapan berikut; pertama, Analisis SWOT. Kedua, Branding School. Ketiga, Pelaksanaan SRA Development. Keempat, Perbaikan Berkelanjutan. Dengan penerapan sekolah ramah anak di RA Nurus salam pembelajaran lebih kondusif serta kpercayaan wali murid terhadap guru semakin tinggi.
\end{abstract}

Kata kunci: Kepemimpinan Perempuan; Sekolah Ramah Anak; Anak Usia Dini

\title{
A. Pendahuluan
}

Sekolah ramah anak atau yang dikenal dengan SRA merupakan kegiatan pendidikan dan pembelajaran yang kondusif, sehat dan bersih serta memiliki kepedulian terhadap lingkungan social dan budaya, siap memenuhi, menghormati dan menghargai hak anak dan memberikan jaminan perlindukungan kepadanya yang disebabkan oleh kekerasan, diskriminasi serta menjaga agar tidak mendapat perlakuan yang tidak baik. Sekolah yang demikian mendukung peran serta anak dalam aktivitas guru pada kegiatian merencanakan, mengimplementasikan dan mengevaluasi pembelajaran. Selain itu, mampu memenuhi terhadap perlindungan pada semua jenjang pendidikan (Yosada \& Kurniati, 2019).

Diantara beberapa policy yang digunakan beberapa lembaga pendidikan dalam mitigasi resiko pelanggaran hak anak adalah sekolah ramah anak (Moh. Dwi Kurniyawan \& Sunandar, 2020). Sekolah Ramah Anak dipahami sebagai tempat pendidikan sekolah yang mampu memberikan hak anak dalam aktivitasnya di sekolah (Tusriyanto, 2020).

Sekolah Ramah Anak sangat penting diterapkan dalam menjamin perlindungan anak dari berbagai ancaman, sekolah ramah anak meliputi SDM tenaga pendidik yang mumpuni, keberadaan sarana dan prasarana dengan memperhatikan manajemen resiko.

Banyak penelitian tentang Sekolah Ramah Anak diantaranya; Çobanoğlu et al., (2018) Mengatakan Sekolah Ramah Anak mengadopsi pendekatan pendidikan berbasis hak yaitu; pertama, Mencegah diskriminasi, kedua, mengedepankan kepentingan terbaik anak. Ketiga, Membuat anak merasa nyaman dan aman. Keempat, membebaskan anak berekspresi. Penekanannya di sini adalah pada akses yang menciptakan kesempatan 
untuk belajar, kualitas yang mendukung perkembangan kognitif dan afektif, dan rasa hormat yang menghargai bahasa, budaya, agama, dan perspektif individu.

Kemudian Abdullahi et al., (2017) mengatakan bahwa sekolah ramah anak, diharuskan setiap anak mendapat tempat belajar yang aman dan nyaman, baik secara emosional maupun secara psikologis. Selanjutnya Moh. Dwi Kurniyawan dan Sultoni (2020) mengatakan sekolah ramah anak memahami dan memberikan seluruh hak anak untuk memperoleh pendidikan dan pembelajaran, mampu mengemukakan pendapat secara bebas, terhindar dari bullying / kekerasan, diskriminasi, dan mampu mengekspesikan dirinya dalam berbagai kegiatan di sekolah. Dipertegas oleh Fauji et al., (2020) bahwa ramah anak disini yaitu memberikan rasa keamanan dan kenyaman kepada peserta didik.

Namun, dunia pendidikan dicoreng oleh kekerasan dalam lingkungan sekolah yang dalam kenyataannya masih banyak terjadi, baik yang dilakukan oleh oknum guru, teman sepermainan atau teman yang beda kelas, baik dalam bentuk kekerasan fisik maupun psikologis (Rozana, Wahid, \& Muali, 2017). Pendidikan ramah anak merupakan conducive learning creation, di mana anak diharapkan mampu belajar secara efektif dengan kondisi yang mampu menyajikan rasa nyaman dan aman serta memberikan semangat belajar yang tinggi (Alfina \& Anwar, 2020).

Fakta di lapangan khususnya RA Nurus Salam, Kotaanyar, Probolinggo yaitu adanya penurunan moral yang mengkhawatirkan, sikap jujur, sikap adik, tolong menolong, perkataan kotor serta kasih sayang bahkan adanya bulliying oleh beberapa anak yang ada di RA Nurus Salam. Para guru merasa kurang sukses dalam menanamkan nilai-nilai karakter terhadap anak didik seperti komunikasi antar anak didik, kejujuran dan kedisiplinan.

Fenomena tersebut memberikan bukti bahwa keamanan tidak selalu anak dapatkan dilingkungan sekolah, karena masih banyak ditemukan kondisi yang tidak diinginkan, bahkan sering terjadi tindak kekerasan dan bullying. Situasi yang yang demikian memungkinkan pembelajaran tidak dapat berkembang. Oleh sebab itu sangat diharapkan adanya Sekolah Ramah Anak dengan tujuan untuk melindungi anak secara fisik dan psikis (Tri Na'imah, Yuki Widyasari, 2020).

Dalam mengatasi hal tersebut diperlukan suatu terobosan baru dalam menciptakan sekolah ramah anak dengan keterlibatan pemimpin yang handal dan mampu mengatasi problematika yang ada (Dakir, 2018). Setiap pemimpin dalam organisasi harus bertipikal manajerial yang wajib dimiliki oleh setiap pemimpin organisasi (Fauzi \& Muali, 2018). Kepiawaian para pemimpin dalam mengarahkan para anggotanya akan menciptakan keefektivitasan kepemimpinanya (Sutanto, 2000). Karena semangat kerja, kenyamanan, keamanan, kualitas pekerjaan serta tingkat prestasi suatu 
organisasi dipengaruhi oleh seorang pemimpin. Sangat dibutuhkan peranan pemimpin dalam pencapaian tujuan suatu organisasi yang optimal.

Pemimpin sekolah yang sukses mengandalkan berbagai keterampilan, ciri kepribadian, dan pengalaman untuk melakukan pekerjaan mereka, menginspirasi, memimpin, dan secara kompeten memenuhi tuntutan masyarakat dan sekolah yang berkembang pesat. Mereka juga berkomunikasi dengan guru, siswa, orang tua, dan pemangku kepentingan sambil mengelola konflik di unit sekolah mereka ( $\mathrm{S} \&$ Oikonomou, 2020).

Pemimpin diwajibkan cakap dan mempunyai keistemawaan/kelebihan, sehingga pimpinan tersebut mampu mempengaruhi orang yang dipimpinnya untuk melakukan berbagai aktivitas secara bersama-sama guna mencapai sebuah tujuan bersama (Fitriani, 2015; Wibowo \& Subhan, 2020).

Semua orang bisa berkesempatan menjadi seorang pemimpin (leadership), begitu pula dengan para wanita, wanita juga bisa bangkit menjadi seorang pemimpin di ibaratkan banguna kokoh maka wanita sebagai fondasinya yang mempunyai struktur kuat (Sabhan, 2016). Wanita menjadi seorang pemimpin dimaknai sebagai penyetaraan gender dengan kaum lelaki.

Arbain et al., (2015) memaknai gender sebagai perbedaan antara laki-laki dan perempuan dalam perspektif non biologis. Gender dapat dipahami sebagai penyetaraan harkat dan martabat kaum wanita dan laki-laki dalam bidang sosial. Pengertian lain mengenai gender dipahami sebagai sebuah konsep budaya yang bertujuan untuk membuat pembeda antara laki-laki dan perempuan dalam hal perilaku, peran, karakteristik dan lain sebagainya (Umriana, Fauzi, \& Hasanah, 2016). Oleh sebab itu gender perlu dilibatkan dalam semua kebijakan, perencanaan dan proses pembangunan (Wahyudi, 2018). Dalam upaya memberikan kesempatan terhadap gender untuk memunculkan bakat dan prestasinya dikalangan umum.

Kebijakan transformatif gender diperlukan untuk memungkinkan perempuan dapat mengintegrasikan sosial, biologis serta peran dan fungsi pekerjaan secara maksimal, dan perempuan yang sehat, dihargai, berkemampuan, dan berdaya akan memberikan kontribusi besar untuk keberlanjutan pengembangan (Ana Langer et al., 2015) Pemikiran kaum perempuan mengalami perkembangan yang signifikan dari tahun-ketahun terutama pada masa sekarang ini. Dapat kita lihat keterlibatan perempuan dikancah politik maupun oganisasi yang semakin banyak, hal ini dapat menjadikan wakil bagi kaum perempuan pada berbagai jenis kegiatan di masyarakat (Hamka, 2013).

Dalam sejarahpun tercatat beberapa wanita yang jaya dapat mewakili dan menduduki jabatan tertinggi baik tingkat kabupaten, tingkat provinsi maupun pusat seperti ketua pengadilan, menteri, perdana mentri, wakil presiden bahkan menjadi presiden (Habibah, 2015), seperti presiden Indonesia yang kelima tepatnya pada tanggal 
23 juli tahun 2021 sampai 20 oktober 2004 dipimpin oleh seorang perempuan yaitu ibu Megawati Soekarno Putri (Nurmalasari \& Karimah, 2020).

Begitu pula yang terjadi pada RA Nurus salam yang memberikan kesempatan kepada perempuan untuk memimpin lembaga tersebut. RA Nurus Salam khususnya membutuhkan pemimpin yang kompeten dalam memanag program lembaga berbasis sekolah ramah anak. Beberapa penelitian tentang keterlibatan perempuan dalam memimpin diantaranya; (Halilah, 2012) menyampaikan kepemimpinan perempuan pada Lembaga Pendidikan juga memberikan pengaruh yang positif terhadap anak didik, karena sikap perempuan yang lemah lembut mampu memahami karakter anak didiknya terutama pada anak usia dini. Perempuan sangat mungkin menjadi kepala sekolah untuk menciptakan lembaga pendidikan yang unggul dan kompetitif, mengingat aspek cinta kasih merupakan insting dari seorang wanita.

Kompetensi kepemimpinan wanita juga dapat menciptakan kepemimpinan yang efektif (Nurvita, Alam, \& Abdullah, 2020). Pemimpin perempuan diharapkan dapat menciptakan pola pengasuhan yang nyaman kusunya pada anak usia dini.

Membentuk generasi yang beriman, berkualitas, tangguh dan ungguh dalam kepribadian, penguasaan terhadap ilmu pengetahuan dan teknologi, sehingga negara akan menjadi negara yang lebih maju serta unggul maka hal ini dipengarui oleh Pendidikan (Yulianto, 2016).

Berikutnya Asmanah Rohmatun Sholehah, Saeful Anwar (2016) berpendapat Ada beberapa keunggulan di antara pemimpin wanita; wanita pertama identik dengan kelembutan, ketenangan dan kerendahan hati. Kedua, sifatnya analitis dan berhati-hati. Melalui karakteristik yang demikian, pimpinan akan hati-hati dalam menentukan suatu keputusan. Ketiga, lebih memahami dan memahami kebutuhan bawahan. Dengan beberapa ciri khas seorang wanita akan memberikan kenyamanan kepada bawahan dalam kepemimpinan.

Pendidikan untuk anak usia dini diharapkan mampu menstimulasi perkembangannya untuk menunjang masa depannya kelak (Abd. Hamid Wahid, Chusnul Muali, 2018). Namun, pada era globalisasi ini banyak terjadinya kekerasan terhadap anak. Berbagai macam kasus kekerasan yang menyeruak ke permukaan di dalam dunia Pendidikan, potret yang paling buram dari rendahnya produk pendidikan di Indonesia yaitu pelecean seksual terhadap anak didik.

Untuk mengatasi problematika pembelajaran tersebut, sekolah RA Nurus salam menerapkan sekolah ramah anak dalam mengatasi permasalahan-permasalahan yang ada dan memberikan stimulus baru dengan SRA agar perkembangan anak tercapai secara optimal. Terlebih, lembaga tersebut memiliki keunggulan, karena dipimpin oleh kepala sekolah perempuan yang cenderung memiliki karakteristik kepribadian dan ciri khas dalam gaya kepemimpinannya. Pemimpin perempuan lebih cenderung memiliki 
karakter keibuan, detail dalam mengamati sesuatu yang ada, cakap dalam berkomunikasi dan lain sebagainya.

Pemaparan dari sejumlah peneliti tersebut menjelaskan tentang pentingnya sekolah ramah anak dalam menjaga hak-hak anak serta perlindungan anak dari kekerasan yang sewaktu-waktu dapat mengancamnya, serta keterlibatan pemimpin perempuan diharapkan mampu untuk menciptakan sekolah ramah anak terutama pada anak usia dini dalam pembentukan karakter yang dibentuk sedini mungkin.

Berangkat dari hal tersebut di atas maka peneliti tertarik mengkaji kembali tentang kepemimpinan perempuan dalam menciptakan sekolah ramah anak, di mana penelitian ini memiliki keunikan dari beberapa penelitian sebelumnya, mengingat karateristik dominan pemimpin perempuan yang ditampilkan oleh lembaga tersebut dan target yang ditentukan (SRA) merupakan bagian terintegrasi yang ada dan dimiliki oleh jiwa perempuan, sehingga hal inilah yang menjadi novelty penelitian ini. Adapun fokus penelitian ini adalah untuk menganalisis dan memahami tentang kepemimpinan perempuan dalam menciptakan Sekolah Ramah Anak.

Penelitian ini mengunakan metode kualitatif jenis studi kasus guna menggambarkan tentang kepemimpinan perempuan dalam menciptakan penelitian. Lokus penelitian ini di Raudlatul Athfal (RA) Nurus Salam, Kotanayar, Probolinggo. RA Nurus Salam adalah pendidikan formal yang menerapkan sekolah ramah anak dalam penerapan pembelajarannya.

Interview dilakukan kepada kepala sekolah dan beberapa guru di RA Nurus Salam. Sedangkan observasi dilakukan pada saat pembelajaran berlangsung. Analisis datanya dilakuakn melalui beberapa tahapan, yaitu penyajian data (data display), reduksi data dan penarikan kesimpulan. Reduksi data dilakukan pada dengan cara memilah dan memilih data, kemudian dikelompokkan sesuai kebutuhan dalam penentuan langkah selanjutnya yang kemudian dilakukan penarikan kesimpulan dari data penelitian. Dari sebanyak data penelitian, selanjutnya di analisa secara berjenjang, yang diawali penyajian terhadap semua data yang ada, kemudian berlanjut tahap reduksi data dengan beracuan pada tema penelitian yang digunakan, serta di akhiri dengan conclusion sebagai sebuah temuan penelitian.

\section{B. Pembahasan}

Kepemimpinan perempuan dalam menciptakan sekolah ramah anak di RA Nurus Salam, Kotaanyar, Probolinggo melalui tahapan sebagai berikut ; 


\section{Analisis SWOT}

Analisis SWOT dipahami sebagai iktiar untuk mengetahui tentang kekuatan, kelemahan, peluang dan ancaman. Keunggulan adalah penjelasan tentang keunggulan sekolah. Kelemahan tidak mendukung bagian dari keberhasilan pendidikan yang ingin dicapai sekolah. Jika potensi sekolah dimanfaatkan dengan sebaik-baiknya, maka peluang merupakan peluang yang dapat direalisasikan. Ancaman merupakan peluang yang mungkin terjadi atau merupakan hasil dari kelangsungan dan keberlangsungan kegiatan sekolah (Sujoko, 2017).

Strengths atau kelebihan dari RA Nurus Salam adalah memiliki SDM yang memiliki kompetensi personal, pedagogic, professional, sosial, yang ditujang dengan sikap guru yang ramah tamah, kasih sayang dan sangat mengedepankan hak-hak anak didiknya, sarana dan prasana yang ada sudah mengikuti standart keamanan untuk anak, seperti memiliki ruang dan fasilitas bermain yang aman dan sehat, masyarakat dan simpatisan alumni yang ikut mendukung dalam menciptakan pelaksanaan sekolah ramah anak serta penerapan bahasa sopan dan santun. Dengan slogan atau motto "Sekolahku Pelindungku" yang ada di RA Nusus Salam sangat cocok untuk menerapkan sekolah ramah anak terhadap anak didiknya.

Weaknesses atau kekurangan yang ada di RA Nurus Salam adalah kurangnya media dan tempat-tempat penunjang sekolah ramah anak yang dimiliki disebabkan oleh faktor biaya yang masih mengandalkan bantuan dari pemerintah. Selain itu, adanya perilaku yang kurang serius dalam kegiatan pembelajaran yang ditunjukakn oleh siswa, yang disebabkan oleh minimnya peran serta orang tua dalam memperhatikan tumbuh kembang anak. Hal ini menjadi PR bagi kepala, semua guru, jajaran staf beserta Yayasan untuk memenuhi media dan tempat yang mendukung dalam pengelolaan sekolah ramah anak.

Opportunity atau kemungkinan-kemungkinan yang akan dicapai oleh sekolah RA Nurus Salam adalah kemandirian sekolah dalam hal pengelolaan bidang pencapain sekolah ramah anak. Melihat dari SDM yang ada meliputi figur guru-guru yang kompeten dalam melindungi hak-hak anak serta kasih sayang yang tercurah kepada anak didiknya.

Threats atau ancaman yang memberikan pengaruh secara berkesinambungan terhadap lembaga RA Nurus Salam yaitu persaingan antar lembaga pendidikan di sekitar yang menerapkan metode yang sama atau bahkan meniru metode yang telah diterapkan oleh lembaga ini. Selain itu, ancaman lain juga datang dari lingkungan sekitar yang kurang memberikan dukungan terhadap pelaksanaan pendidikan di lembaga ini. 
Pendidikan Ramah Anak merupakan lembaga yang mampu memberikan fasilitas serta dapat memaksimalkan potensi anak. Sekolah harus mampu mewujudkan lingkungan budaya yang edukatif, sehat. Maka diperlukan sebuah program perencanaan yang dapat mengembangkan potensi anak melalui keikutsertaannya pada lingkungan sosial maupun lingkungan budaya.

Tujuan sekolah ramah anak yaitu untuk menciptakan, menjamin, serta memenuhi hak-hak perlindungan anak dalam suatu lembaga pendidikan. Dalma hal ini sekolah menjadi tempat yang nyaman dan aman bagi anak dalam kegiatan pendidikan dan pembelajarannya. Kondisi yang nyaman dan aman ini akan mampu menumbuhkembangkan potensi anak sesuai dengan yang diinginkan.

Umi Kulsum sebagai guru RA Nurus Salam mengatakan dalam perencanaan sekolah ramah anak, kepala sekolah beserta jajaran guru dan yayasan serta pihak terkait mengadakan persiapan-persiapan dalam mewujudkan sekolah ramah anak melalui persiapan sebagai berikut; (Kulsum, 2020)

Pertama, persiapan dilakukan pihak Sekolah: mengadakan sosialisasi tentang SRA; membentuk tim, meningkatkan komitmen seluruh komponen sekolah; mengindentifikasi terhadap potensi yang dimiliki; memberikan informasi kepada dinas terkait. Kedua, Penyusunan kebijakan sekolah ramah anak di RA Nurus Salam meliputi; tujuan pembentukan SRA, kesepakatan dalam bentuk penyusunan kebijakan SRA (kepala sekolah, guru, komite, yayasan dan pihak badan konseling). Ketiga, pembentukan tim pelaksana SRA, pembentukan tim berasal dari unsur kepala sekolah, guru RA Nurus Salam, komite, anak didik dan wali murid. Ketiga, persiapan pihak pemda (pemerintah daerah) yaitu; Membuat SK Daerah tentang sekolah ramah anak; membantu pembuatan papan nama.

\section{Branding School}

Berdasarkan wawancara dengan Umi kulsum selaku kepala sekolah. Beliau menyampaikan bahwa RA Nurus Salam melakukan branding dengan beberapa langkah dalam penerapan sekolah ramah anak (Muali, Wibowo, Hambali, Gunawan, \& Hamimah, 2020) (Kulsum, 2020).

Adapun Langkah -langkah yang sudah dipublikasikan dalam melakukan branding school diantaranya; Pertama, mengadakan sosialisasi dan penyuluhan terhadap wali murid dan masyarakat sekitar sekolah, tentang kebijakan sekolah ramah anak RA Nurus Salam. Kedua, menyebarkan brosur RA Nurus Salam dalam pengenalan sekolah ramah anak yang ada dilembaga kepada masyarakat luas. Ketiga, proses pelaksanaan sekolah ramah anak terhadap anak didik diterapkan secara continue. Keempat, sarana 
dan prasarana sesuai standart keamanan sekolah ramah anak. Kelima, pengadaan bimbingan konseling dari guru BK yang kompeten. Keenam, koordinasi dan kerjasama terhadap wali murid, masyarakat sekitar, alumni serta simpatisan dalam menciptakan sekolah ramah anak.

Sekolah RA Nurus Salam mempuai dedikasi yang tinggi terhadap perlindungan anak, kepala, para guru dan staf-staf yang ada di RA Nurus Salam sangat mengutamakan hak-hak asasi anak terutama dalam keamanan anak dalam segi fisik maupun mental seperti motto yang selalu dingaungkan pada lembaga Pendidikan ini yaitu "Sekolahku Pelindungku" dengan motto itu maka RA Nurus Salam harus berinovasi serta berdedikasi menciptakan sekolah ramah anak yang benar-benar mampu melindungi setiap hak anak. 


\section{Pelaksanaan SRA Development}

Dalam melaksanakan sekolah ramah anak diperlukan ikhtiar yang sungguhsungguh dan komitmen dari seluruh komponen sekolah, sehingga terhadapat beberap hal yang harus dilakukan, seperti perencanaan yang matang, menyusun prota; perencanaan konsistensi kebijakan program, kegiatan program, menentukan system pendanaan, system monitoring dan evaluasi, pendampingan dan pelatihan.

Sebelum pelaksanaan maka diperlukan perencanaan terlebih dahulu agar proses pelaksanaan bejalan dengan kondusif dan terarah. Indawati guru RA Nurus Salam menyampaikan perencanaan sekolah ramah anak di RA Nurus Salam dilakukan dengan membuat indikator implementasi yang sudah ada pada delapan standart nasional pendidikan yang dilakukan secara bersama dengan melibatkan seluruh komponen sekolah. Komponen tersebut meliputi; standard isi, proses, standard kompetensi lulusan (SKL), pendidik dan tenaga kependidikan, standard sarana dan prasarana pendidikan, pengelolan, pembiataan dan standard penilaian (Indawati, 2020)

Di dalam indikator implementasi delapan standar nasional pendidikan sekolah ramah anak di RA Nurus Salam menitik beratkan pada kebutuhan anak, kurikulum yang berdasarkan perlindungan anak, tidak diskriminasi serta jauh dari tindakan kekerasan, memenuhi hak-hak anak, pembelajaran berbasis PAIKEM, menampung bakat serta minat anak, menyiapkan kebutuhan anak, mencitakan rasa aman dan nyaman pada anak, memberikan ruang partisipasi bagi anak, dan sebagainya.

Miri Jufria Vinori juga mengatakan dalam perencanaan sekolah ramah anak bukan hanya berpedoman pada pendidik yang terlatih namun juga penyediaan fasilitas alat pendukung yang aman dan ramah anak (Vinori, 2020). Pelaksanaan program sekolah ramah anak mengoptimalkan kebutuhan dengan melibatkan pemerintah, Dunia Usaha dan Industri (DUDI), alumni dan lain sebaginya guna memenuhi syarat-syarat Sekolah Ramah Anak, pendidikan dan pelatihan serta pendampingan. Berikut pelaksanaan SRA Development;

\section{a. Pelaksanaan pembelajaran}

Pelaksanaan metode belajar ramah anak yaitu dengan pembiasaan tanpa adanya tindak kekerasan. Metode ini meliputi; membiasankan anka untuk berpeilaku disiplin tanpa adanya kekerasan, menciptakan interaksi yang baik, penggunaan bahasa verbal yang aman dan tidak memunculkan pelecehan, memberikan motivasi kepada anak, meningkatkan keakraban dalam suanan KBM, dan lain sebagainya.

Penerapan Model Pelaksanaan Pembelajaran Ramah Anak di RA Nurus Salam meliputi; Pertama, menggunakan model pembelajan yang menarik minat anak pada 
situasi yang nyaman, maksudnya agar terciptanya kenyamanan baik guru maupun peserta didik, berbagai masalah yang ditimbulkan oleh anak dapat diselesaikan dengan bijak. Guru lebih mengutamakan perlindungan dan perkembangan anak berjalan secara optimal dengan stimulus-stimulus yang tepat.

Kedua, memberikan kepercayaan dan selalu berprasangka baik terhadap anak yang mempunyai tujuan meskipun dalam melangkah belum tepat. Ketiga, guru menyadari tentang kemampuan anak didik yang baik dan perlu dikembangkan. Setiap potensi anak berbeda-beda maka disinilah tugas guru untuk menumbuhkan potensi anak didik dengan perangsangan yang benar. Keempat, dalam strategi pembelajaran Ramah Anak Ramah Guru, yang timbul yaitu strategi motivasi serta tidak memaksakan kehendak guru. Guru RA Nurus Salam hanya sebagai motivator yang membimbing tanpa harus memaksakan kehendak Kelima, pola pendidikan RA Nurus Salam yaitu dengan pendekatan cinta dan sayang. Peran guru sebagai pembimbing dan orang tua ketika disekolah. Guru juga mengawasi perbuatan anak didik dalam bersosial dengan anak-anak yang lain. Selama berada di sekolah baik di dalam kelas maupun diluar kelas mutlak kewajiban guru dalam mengawasi dan menjamin keamanan anak. Orang tua sudah menyerahkan wewenan penjagaan kepada guru. Diluar sekolah baru orang tua yang aktif menjaga keamanan anak.

\section{b. Sarana dan Prasarana}

Meski dalam keterbatasan biaya namaun pihak sekolah RA Nurus Salam tetap mengupayakan sarana dan prasaran terpenuhi dengan mengikuti standart keamanan untuk anak didik seperti; pertama, keselamatan yang terdiri dari struktur bangunan kokoh, kuat dan stabil, bagunan sekolah memiliki proteksi kebakaran bangunan sekolah tidak berada dibawah jaringan listrik, bangunan menpunyai fentilasi udara. Kedua, kesehatan yang meliputi penghijauan disekitar sekolah, adanya toilet khusus guru dan murid dan tempat cuci tangan. Ketiga, kenyamanan yang meliputi alat pendukung pelajaran seperti meja, kursi, papan yang tidak memiliki siku tajam, tersedia matras diarea permaian dalam serta ape luar juga menghindari siku tajam yang dilindungi dengan spon pengaman. Keempat, kebersihan di mana tersedia tempat sampah disetiap kelas, mempunyai pembuangan sampah yang memadai dan peralatan kebersiha seperti; sabun, hansanitizer, sabun pembersih lantai dan alat pembersih lantai.

\section{c. Lingkungan Pendukung}

Guru yang terlibat dalam penerapan sekolah ramah anak sudah melalui tahap uji kompetensi dalam bidang ramah anak, jadi SDM yang ada sudah terlatih dalam penerapan pembelajaran berbasis ramah anak. Sebelum tahap penerapan sekolah ramah 
anak guru RA Nurus Salam sudah melalui tahap pelatihan SRA, mengikuti seminar SRA serta mengikuti tahap evaluasi pemilihan guru terlatih dalam bidang ini.

Qurraotul Aini salah satu guru RA Nurus Salam juga menegaskan dalam proses penerapan sekolah ramah anak guru-guru dimotivasi oleh kepala sekolah dalam mengikuti seminar dan pelatihan pelaksanaan sekolah ramah anak, agar guru dapat menjalankan tugas sesuai dengan prosedur sekolah ramah anak dan mengembangkan bakat anak sesuai dengan tahapan perkembangannya (Aini, 2020).

Kemudian lingkungan pendukung lainnya yaitu masyarakat disekitar sekolah beserta wali murid yang ikut berperan dalam mewujudkan sekolah ramah anak, mereka juga berperan aktif dalam mengawasi serta menjaga lingkungan sekitar agar sekolah ramah anak yang diharapkan terealisasi dengan baik.

Dalam pelaksanaan jika ada tindakan yang menyimpang maka akan ada mekanisme pengaduan dengan acuan gambar berikut;

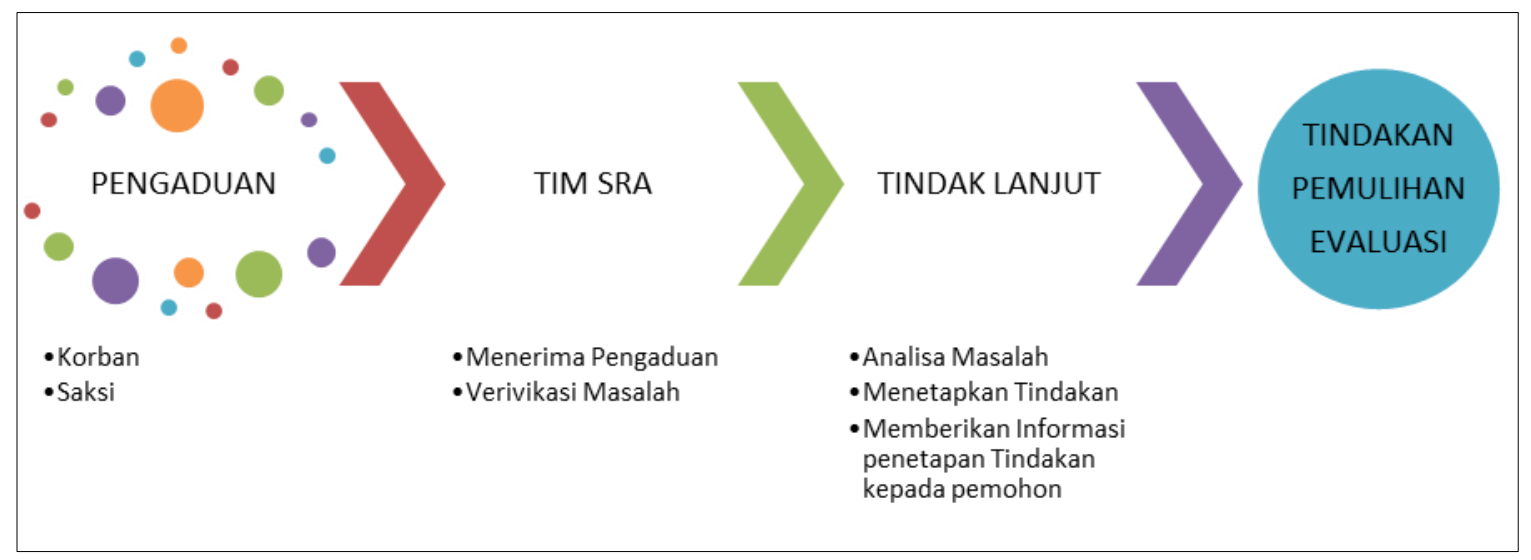

Gambar 1. Alur Mekanisme Pengaduan

Tindakan kekerasan yang dilakukan oleh guru bukanlah cara yang baik untuk mendidik dan membina anak (Dakir, 2014), karena hal tersebut akan menimbukan ketakutan bagi anak dan mampu menimbulkan trauma berkelanjutan. Menekan, memaksa dan mengintimidasi bukan tindakan yang ada di program Sekolah Ramah Anak (Munandar, 2019).

\section{Continous Improvement}

Perbaikan berkelanjutan dilakukan pemantauan agar Sekolah Ramah Anak benar-benar terlaksana di RA Nurus salam dengan menggunakan konsep Deming. Deming Philosophy, memandu implementasi manajemen yang tepat dan baik akan berdampak pada perbaikan kualitas organisasi tersebut. Pengurangan biaya-biaya 
organisasi diakibatkan dari meningkatnya perbaikan kulaitas. Menurut Deming Philosophy kuncinya yaitu perbaikan berkelanjutan guna meningkatkan mutu akan menciptakan organisasi mampu mencapai tujuannya. Deming mendefinisikan mutu sebagai pengembangan yang continue dari suatu sistem yang stabil (Sriwidadi, 2001).

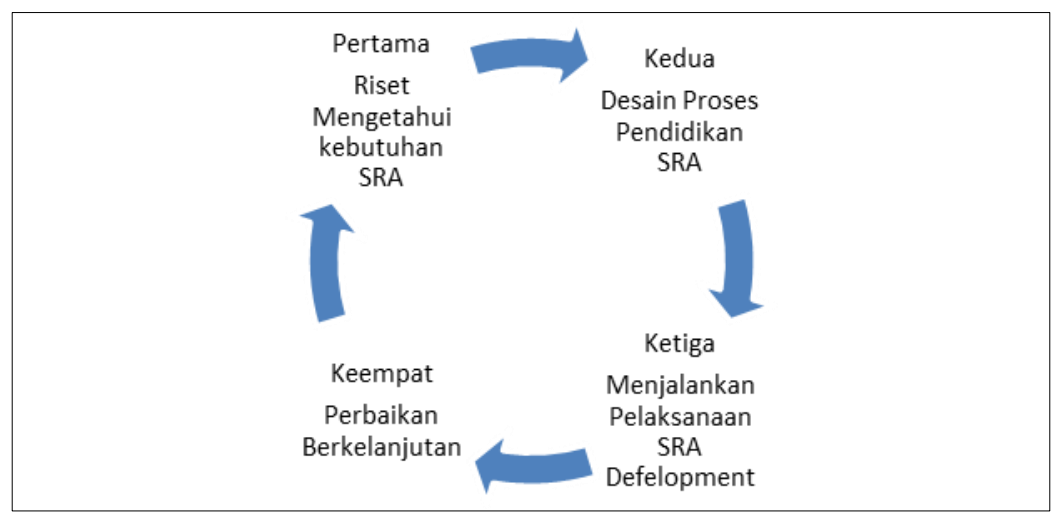

Gambar 2. Konsep Deming SRA RA Nurus Salam

Pemantauan dilakukan oleh kepala sekolah, yayasan dan pihak terkait. Dalam pemantauan ini pihak sekolah memantau seminggu sekali, kemudian dilakukan evaluasi guna mendapatkan hasil yang ingin dicapai dan memperbaiki sistem yang diperlukan. Evaluasi dilakukan sebagai tindakan lanjutan dari pemantauan untuk melakukan pengukuran dan perbaikan dalam kegiatan yang diimplementasikan (Baharun \& Sa'diya Kholifatus, 2018), seperti memadankan hasil-hasil kegiatan. Tujuan dari evaluasi sendiri yaitu agar perencanaan yang telah didesain dapat tercapai secara optimal. Kegiatan evaluasi yang dilakukan, ditujukan untuk merencanakan atau mendesain ulang dari beberapa temuan yang ada, guna menjadi lebih baik. Setelah evaluasi dilakukan maka pihak sekolah akan mengadakan pelaporan terhadap pihak terkait.

\section{Simpulan}

Kepemimpinan perempuan dalam menciptakan sekolah ramah anak di RA Nurus Salam, Kotaanyar, Probolinggo melalui SWOT Analisis, Branding School, Pelaksanaan SRA Development, Continous Improvement. Sekolah Ramah Anak menitik beratkan pada aktivitas yang menunjang terhadap berbagai kebutuhan anak, khususnya kenyamanan dan keamanan di sekolah. Jika semua pihak terlibat dalam membangun sekolah ramah anak baik dari pihak guru-guru, staf sekolah, orangtua, lembaga masyarakat, dan tentunya anak yang ada disekolah tersebut, maka sekolah ramah anak dapat berjalan dengan baik sesuai rencana yang ingin dicapai. 
Sekolah ramah anak di RA Nurus Salam diwujudkan dalam bentuk pendidikan dan pembelajaran yang berkualitas dan inovatif yang mampu memberikan layanan kepada anak didik guna mengembangkan potensinya. Hal ini menjadi kewajiban bagi pengelola sekolah ramah anak. Tentunya penelitian ini tidak dapat digeneralisir untuk semua lembaga pendidikan, karena memiliki ciri, karakteristik, budaya dan lingkungan georgrafis yang berbeda. Oleh karena itu diperlukan penelitian lanjutan dari para peneliti untuk mengkaji lebih mendalam tentang tema tersebut yang memiliki latar / setting dan obyek yang berbeda, sehingga menambah khazanah tentang kepemimpinan dalam mengefektifkan pendidikan dan pembelajaran di sekolah.

\section{DAFTAR PUSTAKA}

Abd. Hamid Wahid, Chusnul Muali, B. S. (2018). Pendidikan Akhlak Perspektif AlGhazali. At-Tajdid: Jurnal Ilmu Tarbiyah, 7(2), 190-205.

Aini, Q. (2020). Interview.

Alfina, A., \& Anwar, R. N. (2020). Manajemen Sekolah Ramah Anak Paud Inklusi. AlTanzim: Jurnal Manajemen Pendidikan Islam, 4(1), 36-47. https://doi.org/10.33650/al-tanzim.v4i1.975

Arbain, J., Azizah, N., \& Sari, I. N. (2015). Pemikiran Gender Menurut Para Ahli: Telaah atas Pemikiran Amina Wadud Muhsin, Asghar Ali Engineer, dan Mansour Fakih. Sawwa, 11(1), 75-94. https://doi.org/10.21580/sa.v11i1.1447

Asmanah Rohmatun Sholehah, Saeful Anwar, H. (2016). Pola Kepemimpinan Perempuan dalam Pengelolaan Yayasan Lembaga Pendidikan. Tadbir: Jurnal Manajemen Dakwah, 1(1), 69-84.

Baharun, H., \& Sa'diya Kholifatus. (2018). Penilaian Berbasis Kelas Berorientasi HOTS Berdasarkan Taksonomi Bloom Pada Pembelajaran PAI. Jurnal Pendidikan Islam, 7(2), 187-204.

Çobanoğlu, F., Ayvaz-Tuncel, Z., \& Ordu, A. (2018). Child-friendly schools: An assessment of secondary schools. Universal Journal of Educational Research, 6(3), 466-477. https://doi.org/10.13189/ujer.2018.060313

Dakir. (2014). Manajemen Layanan Pendidikan Siswa Berkebutuhan Khsusus Prespektif Religious, Filosofis, Yuridis dan Historis. Yogyakarta: K-Media.

Dakir. (2018). Pengaruh Gaya Kepemimpinan Situasional Kepala Sekolah Dalam Supervisi Akademik Terhadap Kompetensi Profesional dan Kinerja Guru. Yogyakarta: K-Media.

Fauji, I., Fahyuni, E. F., Muhid, A., \& Fahmawati, Z. N. (2020). Implementing childfriendly teaching methods to improve qur'an reading ability. Jurnal Pendidikan Islam, 6(1), 69-78. https://doi.org/10.15575/jpi.v6i1.8078

Fauzi, A., \& Muali, C. (2018). Menelusuri Jejak Dan Kiprah Kiai Mohammad Hasan Genggong; Dalam Membangun Kepemimpinan Spritual-Transformatif. Jurnal Islam Nusantara, 2(1), 17. https://doi.org/10.33852/jurnalin.v2i1.56 
Fitriani, A. (2015). Gaya Kepemimpinan Perempuan. Jurnal Tapis, 11(02), 1-24.

Habibah, S. (2015). Kepemimpinan Perempuan Dalam Perspektif Gender. Sosioreligius Volume, 1(1), 101-114.

Hafsatu Umar Abdullahi, Igbaji Clement, Sadiyya Abdullahi Sunusi. (2017). Child Friendly Schools in Nigeria the Role of the Teacher. International Journal of Education and Evaluation, 3(6), 7-12.

Halilah. (2012). Kepemimpinan Wanita Dalam Manajemen Kependidikan. Jurnal: Manajemen of Education, 1(1), 1-9.

Hamka, H. (2013). Kepemimpinan Perempuan Dalam Era Modern. Al-Qalam, 19(1), 107-116. https://doi.org/10.31969/alq.v19i1.222

Indawati. (2020). Interview.

Kulsum, U. (2020). Interview.

Langer, A., Meleis, A., Knaul, F. M., Atun, R., Aran, M., \& Arreola-Ornelas, H. (2015). Women and Health: the key for sustainable development. https://doi.org/10.1016/S0140-6736(15)60497-4

Moh. Dwi Kurniyawan, Sultoni, A. S. (2020). Manajemen sekolah ramah anak. 3(2), 192-198.

Moh. Dwi Kurniyawan, S., \& Sunandar, A. (2020). Manajemen Sekolah Ramah Anak. Jamp: Jurnal Adminitrasi Dan Manajemen Pendidikan, 3(2), 192-198.

Muali, C., Wibowo, A., Hambali, H., Gunawan, Z., \& Hamimah, I. (2020). Pesantren dan Millennial Behaviour: Tantangan Pendidikan Pesantren dalam Membina Karakter Santri Milenial. At-Tarbiyat: Jurnal Pendidikan Islam, 3(2), 131-146.

Munandar, A. (2019). Pengelolaan Lingkungan Dalam Menciptakan Sekolah Ramah Anak Di Min 20 Aceh Besar.

Na'imah, T., Widyasari, Y., \& Herdian. (2020). Implementasi Sekolah Ramah Anak untuk Membangun Nilai-Nilai Karakter Anak Usia Dini. Jurnal Obsesi : Jurnal Pendidikan Anak Usia Dini, 4(2), 747-756. https://doi.org/10.31004/obsesi.v4i2.283

Nurmalasari, I., \& Karimah, D. Z. (2020). Peran Manajemen SDM dalam Lembaga Pendidikan untuk Meningkatkan Mutu Pendidik. MANAGERE: Indonesian Journal of Educational Management, 2(1), 33-44.

Nurvita, A., Alam, F., \& Abdullah, I. (2020). Kepemimpinan Kepala Sekolah Perempuan Dalam Meningkatkan Budaya Sekolah. Jurnal Administrasi Pendidikan UPI, 27(1), 42-52.

Rozana, A. A., Wahid, A. H., \& Muali, C. (2017). Smart Parenting Demokratis Dalam Membangun Karakter Anak. Al-Athfal Jurnal Pendidikan Anak, 4(1), 1-16.

S, A., \& Oikonomou, E. (2020). Effectiveness , Leadership Style And Gender Of Secondary Education School Principals In Athens, Greece. World Journal of Vocational Education and Training, 2(1), 12-20. https://doi.org/10.18488/journal.119.2020.21.12.20

Sabhan, H. (2016). Peran Kepemimpinan Perempuan Dalam Pengambilan Keputusan Di Indonesia. Jurnal Imiah Bongaya (Manajemen \& Akuntansi), 04(19), 57-72.

Sriwidadi, T. (2001). Manajemen Mutu Terpadu. The Winners, 2(2), 107-115. https://doi.org/10.21512/tw.v2i2.3817 
Sujoko, E. (2017). Analisis Swot Di Sekolah Menengah Pertama. Jurnal Manajemen Pendidikan, 4(1), 83-96.

Sutanto, E. M. (2000). Peranan Gaya Kepemimpinan Yang Efektif Dalam Upaya Meningkatkan Semangat Dan Kegairahan Kerja Karyawan Di Toserba Sinar Mas Sidoarjo. Jurnal Manajemen Dan Kewirausahaan, 2(2), 29-43. https://doi.org/10.9744/jmk.2.2.pp.29-43

Tusriyanto. (2020). Pengembangan Sekolah Ramah Anak Di Tingkat Pendidikan Anak Usia Dini. Ri'yah, 05(01), 12-25.

Umriana, A., Fauzi, M., \& Hasanah, H. (2016). Penguatan Hak Asasi Perempuan Dan Kesetaraan Gender Melalui Dialog Warga. Sawwa: Jurnal Studi Gender, 12(1), 41-60. https://doi.org/10.21580/sa.v12i1.1467

Vinori, M. J. (2020). Interview.

Wahyudi, V. (2018). Peran Politik Perempuan dalam Persfektif Gender. Politea: Jurnal Politik Islam, 1(1), 63-83.

Wibowo, A., \& Subhan, A. Z. (2020). Strategi Kepala Madrasah Dalam Meningkatkan Mutu Pendidikan. Indonesian Journal of Islamic Educational Management, 3(2), $108-116$.

Yosada, K. R., \& Kurniati, A. (2019). Menciptakan Sekolah Ramah Anak. Jurnal Pendidikan Dasar Perkhasa, 5(2), 145-154.

Yulianto, A. (2016). Pendidikan Ramah Anak: Studi Kasus SDIT Nur Hidayah Surakarta. At-Tarbawi: Jurnal Kajian Kependidikan Islam, 1(2), 137-156. https://doi.org/10.22515/attarbawi.v1i1.36 